\title{
Essence, Place and Role of Creative Economy in Innovation Development Paradigm
}

\author{
Margarita Vitalievna Savina ${ }^{1}$, Pyotr Viktorovich Solodukha ${ }^{1}$, Ilya Aleksandrovich Stepanov ${ }^{1}$, Irina Petrovna \\ Khominich $^{2} \&$ Andrey Viktorovich Novichkov ${ }^{1}$ \\ ${ }^{1}$ Russian State Social University, Moscow, Russian Federation \\ ${ }^{2}$ Plekhanov Russian University of Economics, Moscow, Russian Federation \\ Correspondence: Margarita Vitalievna Savina, V. Pika, 4, 1, Moscow, 129226, Russian Federation
}

Received: February 28, 2015 Accepted: March 20, 2015 Online Published: April 24, 2015

doi:10.5539/res.v7n6p77 URL: http://dx.doi.org/10.5539/res.v7n6p77

\begin{abstract}
The article is based upon the critical analysis of numerous viewpoints of many authors on the essence and scope of the term "creative economy"; it reveals and describes specialties of socio-economic development of economic system of society at the stage of formation of new information and innovation based method of consumption and production. The article provides the authors' essence and scope concept of "creative economy", specific traits of creative economy (innovativeness, flexibility, responsiveness, unconventional character, globalization, creative thinking, creative projection, multi-direction of social-economic development, etc.)
\end{abstract}

Keywords: creative economy, intellectual environment, knowledge economy, innovations, creative industries, managerial decisions, development strategy

\section{Introduction}

At the stage of postindustrial society one of the major theoretical problems is the definition of economic model of social development adequate to the particularities of innovation of social production.

Researchers from various countries propose different concepts of economic development in XXI century. These models include concepts of innovation economy, knowledge economy, creative economy etc. The scientists are faced with the problem - pointing out principal and characteristic traits of the new economic model of society development, revealing its essence and functioning mechanism.

Of particular relevance innovative or creative economy gains in the diversification of the economies of all the economies of both regions, as well as exclusive territories, so-called "mono-territory" particularly innovative development of such areas can be traced to the diversification into tourism (Kryukova et al., 2013, 2015; Maloletko et al., 2015).

The goal of this article is in scientific generalization, extending and developing theory and methodology of forming of creative economy as an effective model of social economic development of postindustrial society in XXI century.

The scientific hypothesis is that postindustrial economy is based on the widespread introduction the latest achievements of scientific technological, economic and social progress. Under these conditions knowledge economy, innovation economy, creative economy is key factors for increasing the efficiency of social-economic development. The understanding of objective processes and mechanisms of creative economy formation will allow to developing scientifically substantiated provisions and recommendations for creating objective social-economic factors and pre-requisites for creation within the existing technological method of production and consumption, more progressive model of social development.

\section{Methodology}

Theoretical and methodological basis of research were the works of different scientists from various countries on the problems of economic systems development. During the research we implemented abstract, logical, statistical (Kaurova et al., 2013, 2014) factor analysis, system-based analysis and other methods. 
As a result the authors have perfected and developed the theoretical and methodological apparatus of researching the formation and development of economic systems of society, adequate to the particularities of the innovative development direction of postindustrial economy.

Establishment and generalization of scientific approaches to revealing the scope and specialties of creative economy was made using official and statistical information.

The choice of a set of indicators, describing particular characteristics of creative economy, was predicated on a set of methodological provisions reflecting significant characteristics of the main producing force of the postindustrial society, i.e., "creative class":

1) Creative labor of creative class members is based on unconventional, original thinking which is foundation and main essence of their work.

2) Result of creative labor is the produced innovative, creative product.

3) Creative class development within society, its place and role are, to a certain degree, described by the increased share of creative workers, qualified workers and decreased share of other types of workers.

4) Level of creative class development in society is characterized by the dynamics of new knowledge production, inventions, innovations, scientific discoveries and patents, rate of implementation of technological progress in economy, their export and import.

5) Creative class as a vessel of intellectual potential of postindustrial society is characterized by level of education, number of qualified workers, number of specialists that have obtained the latest knowledge and skills.

\subsection{Signs-Indikatorvyateley, Reflecting the Level of Development of the Creative Economy}

Based on these methodological provisions we have been able to specify and propose a set of indicators describing the level of creative economy development in postindustrial society, as well as the role and place of creative class. First group. Characteristics and indicators reflecting the level of development, place and role of creative class:

1) Investment in labor force (human capital);

2) Number of post-graduate students and doctoral candidates as forms of training the teaching personnel and scientific personnel;

3) The amount of developed and implemented advanced technologies in production, including unique and breakthrough technologies;

4) Volume of innovation activity devoted to transformation of ideas into new or perfected product and technological innovation;

5) Efficiency of research and development (number of created and used latest production technologies, based on significant pioneering or highly effective inventions that have no equivalent counterparts domestic or foreign, that have new characteristics compliant with the current technological demands);

6) Level of creation and distribution of technological innovations;

7) Creation and implementation of information and communication technologies;

8) Rate of implementation and use by the enterprises of communication and information technologies, expenditure on communication and information technologies during the companies' day-to-day functioning;

9) Patent applications and patents received;

10) Change in number of innovation driven enterprises and volume of innovation based products.

Second group. Characteristics and indicators describing the level of creative economy development:

1) Government funding of sciences;

2) Internal expenditure on research and development;

3) Investment in scientific technological progress;

4) Volume of trade with foreign countries in technologies.

The place and role of the creative class in the structure of the Russian economy and the United States are presented in the table. 
Table 1. The place and role of the creative class in the structure of the productive classes of society Russia and the United States at the beginning of the XXI century

\begin{tabular}{lll}
\hline \multirow{2}{*}{\begin{tabular}{l} 
The main $\begin{array}{l}\text { of society } \\
\end{array}$ \\
\cline { 2 - 3 } Creative Class
\end{tabular}} & Russia (2012) & USA (2000) \\
The working class & 27.6 & 30.1 \\
The wait class & 39.1 & 26.1 \\
Agriculture & 29.4 & 43.4 \\
In general economy & 3.9 & 0.4 \\
\hline
\end{tabular}

Discription: Source: Calculated by the authors based on Rosstat and Florida R. "Creative Class people who are changing the future".

\section{Results}

\subsection{Pluralism of Creative Economy Concepts}

The term "creative economy" is becoming more widely used among the economists and managers. According to many well-known researchers, creative economy is becoming and will be the leading form of social economic development (Hakimova, 2011). According to them, formation of the intellectual environment, the system of social-economic relations will allow to develop creative capabilities of people, development of new ideas and their implementation. It is creative economy that will be the driving force of creative energy implementation under the conditions of postindustrial society.

At the same time the scientific literature does not provide a unified approach to the term "creative economy". Quite often the category "creative economy" is intertwined with such terms as "knowledge economy", "innovation economy" and "postindustrial economy" among others.

This article looks into the problem of essence, scope and forms of creative economy.

The analysis carried out has shown that in postindustrial society new type of economy is formed and developed which different authors define as "creative economy", "intellectual economy", "knowledge economy" "innovation economy" etc. however the common ground between all types of economy is that the main resource of social-economic development and growth is the widespread usage of latest innovation technologies, new scientific knowledge and innovation in production (Maksimtseva, 2010).

\subsection{Particularities of Innovation Economy Concept}

Currently there are different viewpoints on the scope of the term "innovation economy".

Some authors characterize innovation economy as economy of society based on knowledge innovation, favorable approach to new ideas, technology and readiness to realize new discoveries in different branches of industry. At the same time priority is given to scientific knowledge and innovation in public production development. The authors of this innovation economy concept state that the industries that don't constantly use new knowledge and innovations lose their advantage (Zhuravlev, 2010).

Another definition of innovation economy characterizes it as a type of economy in which profit is created not through material production (industrial economy) and not through financial centers concentration. Innovation economy allows to generating significant volumes of innovations as a result of which technological basis of production is changed (Ismailov \& Gamidov, 2003).

The literature survey has indicated that modern scientists identify "innovation economy" with "knowledge based economy", "creative economy", "information economy", "knowledge economy".

Theoretical research has shown that up until this point "knowledge economy" has more than one meaning in economic theory.

The first meaning includes elements pertaining to one of the fields of economy specifically where new knowledge and technology are created.

However as the "knowledge economy" grows under the conditions of intensive economic growth achieved by new results in science and innovation, with the achievement of education level of the population the term "knowledge 
economy" began to take on another meaning. Simultaneously the term "knowledge-based economy" became widespread. The meaning of "knowledge economy" and "knowledge-based economy" described a type of economy where knowledge became the main production resource that (Frank \& Cook, 1995).

The third meaning is found on the junction between economics and politics, where "knowledge economy" is used in a general sense to describe the future society that modern civilization is striving to achieve. The term is used in this meaning as something ideal yet unattainable, what we have to move towards in order to increase the rate of GDP growth (Toffler, 1999)

Today there is no unified definition of "knowledge economy". That's why we have conducted a research of various viewpoints on the scope of this category.

The research has shown that sociology uses quite frequently the term "Information society, reflecting society that exists within knowledge economy.

Term "information technology economy" describes one of the contemporary approaches to describe modern economy.

As an alternative to "knowledge economy" one can use the term "creative economy".

It is known that knowledge more that neoclassical economy erases the borders between public and private goods, at the same time knowledge society equally shares the public goods between its members.

Also knowledge economy does not limit itself to production economy. It is an elaborate complex, conglomeration of various institutions aiding the formation of the driving force of postindustrial society based on science. This complex includes fundamental sciences establishments, universities, modern communication systems, applied scientists, patent offices (Murray \& Ground, 1984).

However the major point, setting knowledge economy apart from neoclassical economy is fact that neoclassical economy differs from general economic exchange that if in knowledge economy you sell knowledge it does not mean that you lose it, knowledge still remains with you. Someone else buys it. This radically changes the exchange process. If the process of exchange changes this dramatically then existing theory should be changed. This means that economic models including the model of equilibrium are founded on standard exchange processes and are not applicable to describe the knowledge economy.

The basic notion of economic theory is the notion of exchange. Economy is exchange of items. Item exchange for a unit of value that has to be selected as goods, or symbols of value, i.e., money of assets. But what happens in a general situation in economic process? And exchange of property takes place. These objects trade owners. The relations of property change during the process of trade.

The balance between knowledge and resources has shifted towards the former so much that knowledge has become one the most important factors determining the standard of living-more important than land or instruments or labor. Today the most developed economies are based on knowledge.

In the last 200 years neoclassical economy has determined only two factors of production: labor and capital. However today information and knowledge can replace capital and energy becoming major assets, as capital and energy replaced land and labor 200 years ago. Moreover, technological discoveries of the $20^{\text {th }}$ century transformed the principal professions providing welfare from labor based to "knowledge based". Technology and knowledge are the key factor of production today. (Savina \& Stepanov, 2008)

\section{Discussion}

\subsection{Knowledge Economy Management Problems}

Knowledge economy addresses the particularities of "working with one's knowledge", managing it to be precise. Knowledge management means the skills to collect, structure, store, develop (including in specific direction) and sell knowledge.

One has to understand that with knowledge management knowledge has no quantitative equivalent. Of course there are theories and methods of assessment of value and quantity of knowledge but in any case at the point of assessment knowledge turn to information content—-knowledge in digital form. Information content is s module of information with a specific structure which is means of transferring knowledge.

Based on this we can give another, more practical definition to knowledge management-transforming different types of knowledge into structured modules for future use, processing, distribution, trade and exchange.

The social consciousness of the modern economic space is undergoing change. There appear new, important problems for understanding the economic trends and in these conditions the specialists are required to have 
theoretical knowledge and skill in creative thing, unconventional decisions and adaptability to innovation (Pochepina, 2012).

New ideas and knowledge moving in society via cultural layers are preserved and realized as actual constructs which can quickly disappear or exist for millennia. Such transfer processes of search and translation of information are the foundation of economy (Mancur, 1965).

Let's address the term "innovation economy". While researching the essence of an economic phenomenon which in its concentrated form should reflect the category "innovation economy" we have used the methodological approach based on studying the generic term of this category, key here being innovation.

Economic relations appearing in the process of economic activity can be described as innovation economic relations, which with conglomeration of their objects, subjects, their needs, interests and goals including the enforcement mechanisms form innovation sphere of the economic system and serve as the development factor of the latter. In case when innovation economic relations become a widely used development factor of economic systems then it transforms into innovation economic system.

Thus, innovation economic activity is a specific system of economic relations that appears between people about creation, implementation, distribution, consumption and updating the innovations (Stepanov, 2013).

Objects of innovation economic relations are various novelties, innovations.

Subjects of innovation economic relations include the society represented by the government, leading production classes of society, ruling elites, economic subjects and organizations and individuals connected with the transfer of the object of innovation activity.

Within the system of economic relations innovations are in their essence a type of good. The specialty of this good is that dependent on the stage of life cycle it can be in different forms of materialization: idea, research paper, technical documentation, patent, prototype, pre-production prototype. It is obvious that with the materialization the innovation factor of the good declines. At the production stage it become common and its innovation factor can be viewed only within catching-up markets, producers or consumers.

Based on the primary methodological provision the goods in market economy under innovation activity is:

1) For producer-companies - materialized ideas (new technologies), brought to practical usage, when all theoretical and practical problems are solved and commodity can be used commercially. Economic efficiency of the good comes as increase of producer's profit and as increase in consumer attributes and consumers' profit. Developers, producers and consumers of the commodity take part on market relations;

2) For the developer: Scientific idea. As a commodity it is not material and can be at different stages: theoretical, applied studies, development project. Consumers of this commodity are big companies with significant scientific-technological potential; innovation venture companies, specializing in developing new technologies. Naturally commercial approach to financing under these conditions is not quite effective, that's why it should be aided by the government support system: budget and non-budget financing, subsidies and subsidized loans. Innovation activity efficiency is determined by innovation infrastructure. That's why innovation infrastructure is the basic component of the innovation economy, innovation potential of society (Lopatnicov, 1987).

Economic relations appearing during the innovation economic activity can be characterized as innovation economic relations conglomeration of their objects, subjects, their needs, interests and goals including the enforcement mechanisms form innovation sphere of the economic system and serve as the development factor of the latter. In case when innovation economic relations become a widely used development factor of economic systems then it transforms into innovation economic system.

Innovation economy demands excess of knowledge various alternative scientific ideas, unconventional solutions excess of scientific discoveries and ideas in innovation economy initializes regardless of the fact if they will ever reach production.

Innovation economy houses effective stimulation system for creation of different development companies. This is done by creating collective equipment usage centers, techno parks, special taxation areas, and privileges. Simultaneously there should be an excess of financial institutions working in innovation economy so that investors would compete for the possibility of buying start-up shares.

Innovation economy is based on creation of new markets. New markets of ideas, developments, intellectual property, innovation products, whereas old structures are taken down or transformed into something new. A separate market for creation of new organization forms for companies and structures of innovation economy. New 
structures are used such as technological parks at the universities, corporate education centers, clusters for small businesses, business - incubators, technology transfer centers, special trading platforms for innovative products.

Information technologies, computerized systems and new production technologies are the basis systems of innovation economy. As they develop they radically transform the means of obtaining, transferring and production of information, adding technological aspect to intellectual activity (for instance, automation of projections and technological preparation of production, automated control over production, automation of accounting and organizational activity, multi-language automated translation, diagnostics and image recognition, etc.).

Realization results of the new innovation economy should bring achievement of higher level of social-directed research, increase in standard of living as a result of increased social production productivity, a new level of conserving the resources and ecologic stability of economy.

Generalization of literature has allowed to basic principal particularities of innovation economy in postindustrial society that can be expressed in the following:

1) First, increasing role of human capital, human potential as the major factor of development of social production, providing highly intensive growth;

2) Second, dominating role in the process of social production of intangible factors of intellectual capital (intellectual property);

3) Third, widespread development of science based production and products in all fields of economy (Konkov, 2006).

The formation of the conceptual model of creative economy should be made based on regulating impact of the government in creation, development and efficient use of creative class as a factor of innovation economy development (Chuguenko \& Bobkova, 2013).

\subsection{Place and Role of Creative Economy in Postindustrial Society}

Term creative economy was first introduced in 2000 by J. Hoskins. Primarily creative economy reflected efficient development of creative business. According to him, the specialty of creative economy is in the system of specific social-economic relations between the economy and creative approach to its development and advance. In the end it leads to the creation and development of a new creative sector in postindustrial economy that intensely utilizes creative potential (Hoskins, 2000).

Another interpretation of "creative economy" was given by Richard Florida. He based the particularities of creative economy on the characteristics of professions associated with creative industry (Florida, 2005).

Currently "creative economy" is associated with "knowledge economy". It deals with a specific sector of economy based primarily on different types of intellectual labor. We think that this interpretation is true only to a point. However we believe that creative economy cannot be limited to just one characteristic.

Other characteristics include creative thinking, creative projecting that have practical importance as shown by a number of authors.

Creative economy finds its outlet in a variety of ways for socio-economic development. It is a motivator, providing attractive investment climate, modernizing education and science, developing social sphere etc.

At the same time, to be fair we have to point out that creative economy based on intellectual labor creative approach exists not only in socially-oriented and socially important fields of activity. It clear expression (as generation and realization of unconventional ideas) is seen in expanding shadow markets, corruption and criminal socio-economic processes. Lately it's been more often seen in scientific and educational fields, innovation activity, healthcare, construction, and migration, ecological and other sectors of economic development. Within the creative economy paradigm there are two competing tendencies of progress and regress in socio-economic development, forming new socio-economic and cultural relations, new types of creative and economic relations.

All this allows (under certain provisions) to unite different schools of creative economic activity into a singular, independent "creative" sector of economy.

What is the term of Creative economy and what are its particularities?

Researching the economic essence of creative economy we have used the methodological approach addressing the generic terms of this category: "creative" и "есonomy".

The category "economy" as it is known come from Greek "oikonomike", which means "household management". 
At the same time economy is part of human activity, where essential goods are created, that include everything, that satisfies needs. As goods are divided in to natural (land, forests, natural resources, that is created by nature) and economic goods (products that are a result of human activity), then it becomes obvious, that the main function of economy - creation of products, essential for society's livelihood.

Increase and changes in needs form stimuli for creating new goods in order to satisfy new needs. Such needs can be satisfied in different ways and by different means in course of production - both traditional, well known means, and unconventional, original, unique, creative means.

Creativity-from eng. "creative"-means creativeness. Up until recently both in Russian and foreign literature these terms were viewed as synonyms. Currently some authors differ these categories.

The category creativity is more associated with the ability of a person to find new, unique, original ways of solving problems, based on new knowledge, skills, and competencies. The notion of "creative person" was introduced

According to Samorodova (2008) creative person - is a specific type of person, that has the ability to self-replicate new knowledge, skills, and competencies. Creative person has the abilities to thin unconventionally, generate new ideas and come up with solutions.

Creativity (Golovin, 2001) (creative ability, creative activity, creative approach) - is a capacity to generate unusual ideas, deviate from traditional ways of thinking, quickly and efficiently perform the intellectual breakthrough solving complicated tasks.

The best known forms of creativity are: innovations - advancement of conceptually new ideas, novations; inventions - creation of something new, unknown before; discoveries — something newly documented, allocated.

Major factors determining creativity are on the one hand personal qualities as fluency, accuracy, flexibility, originality, inventiveness, constructivity, etc., on the other hand, life experience and individual knowledge of a person in a particular field. The latter is able to bring benefits but also is a limitation factor (Diltz, 2003).

Through creativity one can discover new, impossible at first sight rational connections.

Creativity is expressed in activation of the originative potential of a person, his approach to generate new ideas and solutions to problems. Creativity is the individual's capability reacts to various innovations in time.

Creativity is a complex process that includes mental and psychological processes. Psychological aspects can be developed at training sessions. Our training session, being professions training, primarily views mental apparatus as an effective instrument of creative managerial activity.

Creativity as a mental process is expressed and realized via logical verbal, aspects of creativity that determine in various combinations creative capabilities of a person.

Creative process can be conscious or unconscientious. It is much easier to realize what you are doing, than how you are doing it.

Thus, term creative person and consequently creativity are associated with original form of thinking, differentiating from commonly used logical patterns and a possibility to discover, find and realize new connections between events and processes; secondly, creativity is associated with the capacity to bring something new, original, unique into different fields of practical activity; thirdly, constant readiness to solve substandard problems (Samorodova, 2008).

From the aforementioned meanings of "creativity" and "economy" we propose a new definition of "creative economy". Creative economy is a specific form of socio-economic relations, emerging about production, distribution, exchange and consumption, based on conceptually new original knowledge, unconventional skills, capabilities and competencies, providing solution of problems through new, unique solutions.

Creative solutions in economy are a result of creative approach in making managerial decisions. Creative decisions in economy are expressed primarily in highest efficiency of solving social economic problems and with high efficiency of social-economic activity.

Creative economy is based on the methodology of making unconventional, unique managerial decisions, both with the goal of strategic development, and overcoming constantly emerging emergency and critical situations, when it is needed to implement search and realization of conceptually new ways of survival, advancement, achieving competitive position on the market, and in the end gaining success in competitive struggle. 


\section{Conclusion}

After performing the research we have been able to improve and develop theoretical and methodological apparatus for examining the problems of formation and development of creative economy in postindustrial society. We have defined and revealed characteristics, scope, place and role of creative economy in advancing socio-economic development. We have been able to prove the role of creative economy and primarily creative class as deciding factors, major driving force of social production towards progress.

Theoretical importance of research is in creation and development of theory and methodology of creative economy development, its leading production society class - creative class ass key factor, social initiator and driving force of technological production and consumption evolution.

The research has proven that the main characteristic of creative economy is existence of well-developed creative class whose traits are:

1) Common values, among which creativity is primary, creative unconventional thinking, individuality (certain individual traits) and importance of personal achievements. The essence of labor activity by the creative class representatives are associated with creative work, that stems from unconventional, unique, creative thinking;

2) Individuality, variety, openness, mobility, affectation towards individual expression and personal achievement;

3) Creative class values personal capabilities and merits, ambition, professional growth, professional reputation;

4) Creative class through its activity eliminates bureaucracy and technocracy establishing meritocracy as social governing principle;

5) Representative class earn their living, creating and developing innovation product individually whereas working and service classes perform the work in accordance with plans and timetables;

6) Creative class is free from exploitation (Stepanov \& Savina).

\section{Reference}

Charles, M. (1984). Lossing Ground: American Social Policy (pp. 1950-1980). New York: Basic Books.

Chugunenko, V. M., \& Bobkova, E. M. (2013). Novie tendencii v issledovanii socialnogo samochuvstvia naselenia. SocIs, $1,15$.

Florida, R. (2005). Kreativni klass: Ludi, kotorie menyaut budushee (XXI, p. 421). M.: Klassika.

Hakimova, E. R. (2011). Sovremennie teorii kreativnoy economiki.Ekonomika kreativnosti Marka Mettusa. Vektor Nauki TGU (Seria “ekonomika I upravlenie”), 4(7).

Ismailov, T. A., \& Hamidov, G. S. (2003). Journal of Innovation. Retrieved from http://stra.teg.ru/lenta/innovation/515

Kaurova, O., Maloletko, A., Yumanova, O., Kryukova, E. M., \& Deryabina, A. V. (2014). Modern trends in development of tourism statistics in world and in Russia. Life Science Journal, 11(4), 451-454.

Kaurova, O., Maloletko, A., \& Yumanova, O. (2013) Cross-country Comparison of Statistical Indicators. Life Science Journal, 10(4), 1915-1917.

Konkov, A. T. (2006). Socialniy capital kak koncepcia ekonomicheskoy sociologii I ego rol v sisteme ekonomicheskogo vzaimodeystvia. Avtoreferat dissertacii na soiskanie uchenoy stepeni doctora socialogicheskih nauk. M.

Kryukova E. M., \& Makeeva, D. R. (2013). Analysis of world and Russian best practices of strategic development of mono-towns. World Applied Sciences Journal, 27, 167-171.

Kryukova, E. M., Vetrova, E. A., Maloletko, A. N., Kaurova, O. V., \& Dusenko, S. V. (2015). Social-Economic Problems of Russian Mono-Towns. Asian Social Science, 11(1), 258-267.

Lopatnikov, L. I. (1987). Ekonomiko-matematicheskiy slovar. M.: Nauka.

Maloletko, A. N., Kaurova, O. V., Kryukova, E. M., Pochinok, N. B., \& Gladko, E. A. (2015). Analysis of key indicators of tourism industry in Russia. Modern Applied Science, 9(3), 25-33.

Mancur, O. (1965). The Logic of Collective Action: Public Goods and the Л Groups. Cambridge: Harvard University Press.

NLP: Upravlenie kreativnostiu (pp. 51-54). (2003). R. Dilts-Spb.: Piter.

Pochepina, A. S. (2012). Razvitie kreativnogo klassa v sovremennoy Rossii. Kreativnaya ekonomika, 12(72), 
$9-12$.

Robert, F., \& Philip, C. (1995). The Winner-Take-All-Society. New York: Martin Kessler Books at The Free Press.

Samorodova, D. (2008). Kreativnost: Mify I realnost (pp. 44-51). Smena: Yanvar.

Savina, M. V., \& Stepanov, I. A. (2008). Transformacia sistemi socialno-trudovih otnosheniy v ekonomike rynochnoy orientacii. Problemi formirovania glavnoy proizvoditelnoy sily postindustrialnogo obshestva (teoria I praktika) (pp. 56-73). M.: Staraya Basmannaya.

Toffler, A. (1999). Tretia volna (p. 60). M.

Zhuravlev, V. A. (2010). Kreativnoye obshesto I kreativnaya economika. Novaya ekonomika, 2(C), 24-30.

\section{Copyrights}

Copyright for this article is retained by the author(s), with first publication rights granted to the journal.

This is an open-access article distributed under the terms and conditions of the Creative Commons Attribution license (http://creativecommons.org/licenses/by/3.0/). 